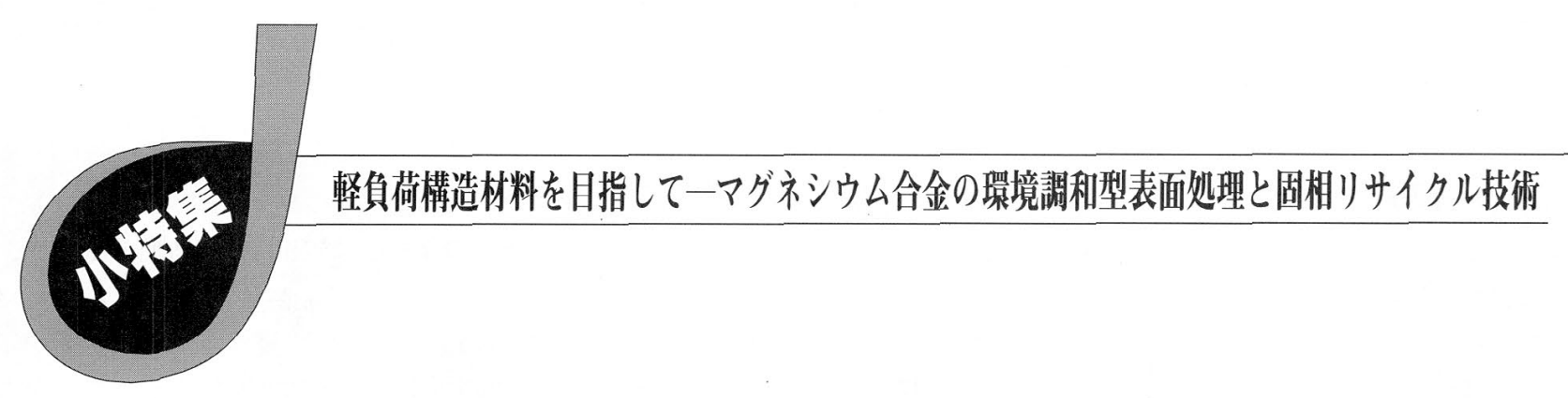

\title{
マグネシウム合金のクロムフリー 化成処理技術
}

\section{梅 原 博 行* 高 谷 松 文**}

\section{1.はじめに}

マグネシウムおよびその合金への化成処理は，塗膜の密着 性向上のための下地処理や耐食性の付与として重要な表面処 理技術である。化成処理は亜鉛めっきやアルミニウムに対す るクロメート処理技術に代表される表面処理であり, コスト が安価で防錆効果に優れて抢り，製品の耐久性向上に不可欠 である，塗装性，高耐食性などの高機能化が可能である，な どの特徴があるため, 幅広く使われている。このため, マグ ネシウム合金に対しても無水クロム酸や重クロム酸塩などの 6 価クロムイオンを含む処理浴が多く使用されてきた ${ }^{(1)}$ 。し かし, EUでの電気電子機器を対象とした有害物質(水銀, カドミウム, 鉛, 六䛧クロム, PBB, PBDE) の使用を制限 する RoHS 指令案 $(\mathrm{RoHS}=$ Restriction of the use of certain hazardous substances in electrical and electronic equipment) にも見られるように，環境負荷物質削減の社会的要求が高ま る中，6 価クロムを含まない化成処理法に対する二一ズが高 まり，クロムフリーの化成処理方法の開発が行われてきてい る.このような動きの中でアルミニウムやその合金について は 6 価クロムを含まないマンガン系, ジルコニウム系, チ タ二ウム系などの化成処理法が提案されて㧍り，一部使用さ れている(2)-(4)。またマグネシウム合金についてもマンガン 系を主とした処理法の開発が盛んになっている(5)-(9). しか し, クロメート处理と同様の廉価で耐食性に優れた化成処理 技術の開発は今後の課題となっている.

ここでは, クロムフリーの化成処理として過マンガン酸カ リウムを主成分とした数種類の比較的単純な浴からの化成処 理皮膜の作製を試久, 得られる皮膜の組成や構造を解析する
とともに，化成処理材の電気化学的特性や耐食性塗装皮膜々 の密着性などの評価を行った結果について述べる.

\section{2. マンガン系化成処理方法}

供試材には，AZ91D マグネシウム合金を使用し，機械的 研磨 (エメリ一紙\#800仕上げ)後, 脱脂処理 (アセトン), 活 性処理 $\left(\operatorname{HF}\left(0.2 \mathrm{~m}^{3} / \mathrm{m}^{3}\right), 60 \mathrm{~s}\right.$ 浸せき) 後水洗の工程により前 処理を施したのち，化成処理を行った(図1参照)。化成処理 浴は主成分として過マンガン酸カリウム $\left(\mathrm{KMnO}_{4}\right)$ を, 添加 剂に硝酸 $\left(\mathrm{HNO}_{3}\right)$ 㧍よびふっっ酸 $(\mathrm{HF})$ 等を含む酸性浴と同じ く過マンガン酸カリウムに加え, 四ホウ酸ナトリウム(ホウ 砂) $\left(\mathrm{Na}_{2} \mathrm{~B}_{4} \mathrm{O}_{7} \cdot 10 \mathrm{H}_{2} \mathrm{O}\right)$ と塩酸 $(\mathrm{HCl})$ を含む中性から弱アルカ リで安定な浴を使用し，298～343 K の浴温度で所定時間処 理を行った。

マグネシウム合金の化成皮膜形成は, $\mathrm{KMnO}_{4}$ 単独の水溶 液中に抢いて著しく緩慢であり, 生成皮膜は非常に薄く, 濃 度および浴温度の影響は顕著には認められなかった。 そこで

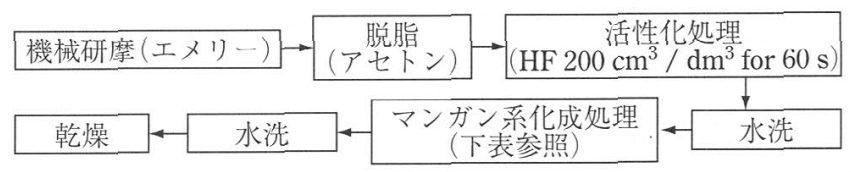

化成処理浴の組成 $\left(\mathrm{mol} / \mathrm{m}^{3}\right)$

\begin{tabular}{|l|c|c|c|c|c|}
\hline Bath 1 & $\mathrm{KMnO}_{4}$ & $\mathrm{Na}_{2} \mathrm{~B}_{4} \mathrm{O}_{7}$ & $\mathrm{HF}$ & $\mathrm{HNO}_{3}$ & HCI \\
\hline Bath 2 & 20 & - & $20-200$ & - & - \\
\hline Bath 3 & 20 & - & - & $20-200$ & - \\
\hline Bath 4 & 20 & 100 & - & - & $50-200$ \\
\hline
\end{tabular}

図 1 マンガン系化成処理プロセス.

* 産業技術総合研究所計測標準研究部門材料評価研究室長 (テ305-8565 つくば市東1-1-1 中央第 5)

** 千葉工業大学教授; 工学部機械サイエス学科

Chrome Free Conversion Coatings for Magnesium Alloy; *Hiroyuki Umehara, **Matsufumi Takaya(National Institute of Advanced In dustrial Science and Technology, Tsukuba. **Dep. of Mechanical Science and Engineering, Chiba Institute of Technology, Narashino) Keywords: conversion coating, potassium permanganate, film structure, XPS, corrosion resistance, salt spray test 2003年12月26日受理 
添加剂の皮膜形成への影響を検討するため素材の質量変化を 求め, $\mathrm{KMnO}_{4}$ を主成分とした浴からの化成皮膜形成に関す る基本的な浴特性について検討した.

無添加浴からの化成皮膜は，先に述べたように質量変化が 小さいが, $\mathrm{HNO}_{3}$ 添加浴においては，添加量を増すに伴い質 量が増加した。 また $\mathrm{H}_{2} \mathrm{SO}_{4}$ 添加浴では添加量を増すにつれ て質量が減少し, $\mathrm{HNO}_{3}$ 添加浴とは反対の傾向を示した。さ らに HF 添加浴では添加量の多少にかかわらず大きな質量変 化が認められなかった．以上の結果から酸性の化成処理浴と して以下の 2 種類を選択した。添加剤としては皮膜形成時 の質量変化が特徵的な $\mathrm{HNO}_{3}$ と $\mathrm{HF}$ を選び， $\mathrm{KMnO}_{4}$ 濃度を $20 \mathrm{~mol} / \mathrm{m}^{3}$, 添加剂の濃度を $100 \mathrm{~mol} / \mathrm{m}^{3}$ とし，浴温は 313 $\mathrm{K}$ とした.

化成処理皮膜の生成過程においては，アノード反応として マグネシウムの溶出が起こる，そのため過マンガン酸カリウ ムを主成分とする中性付近の単純な浴では処理時間の増加 （処理面積の増加）にしたがって処理浴の $\mathrm{pH}$ が高くなり，皮 膜の析出速度や析出する皮膜の特性が変化する．とこで中性 付近の処理浴では $\mathrm{pH}$ の安定性を向上させる目的で緩衝作用 を有する浴組成として種々の組成を検討し，四ホウ酸ナトリ ウム (ホウ砂) $\left(\mathrm{Na}_{2} \mathrm{~B}_{4} \mathrm{O}_{7} \cdot 10 \mathrm{H}_{2} \mathrm{O}\right)$ と塩酸 $(\mathrm{HCl})$ を含む過マン

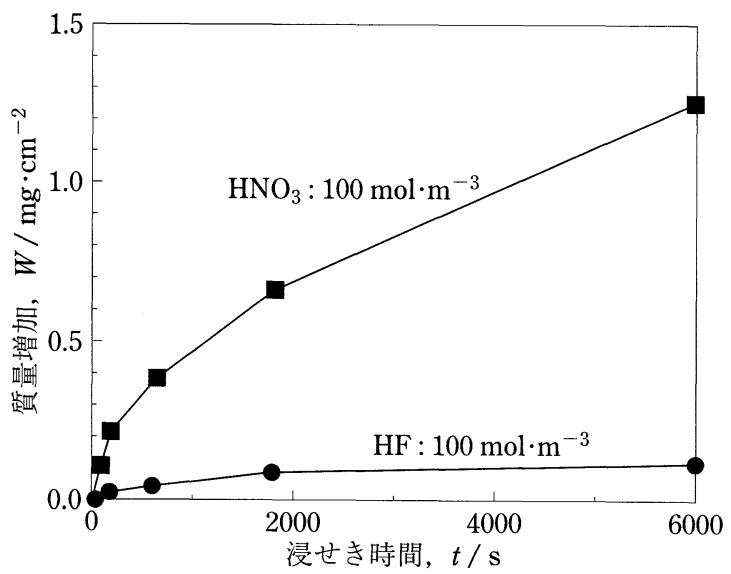

図 2 化成処理による質量増加。

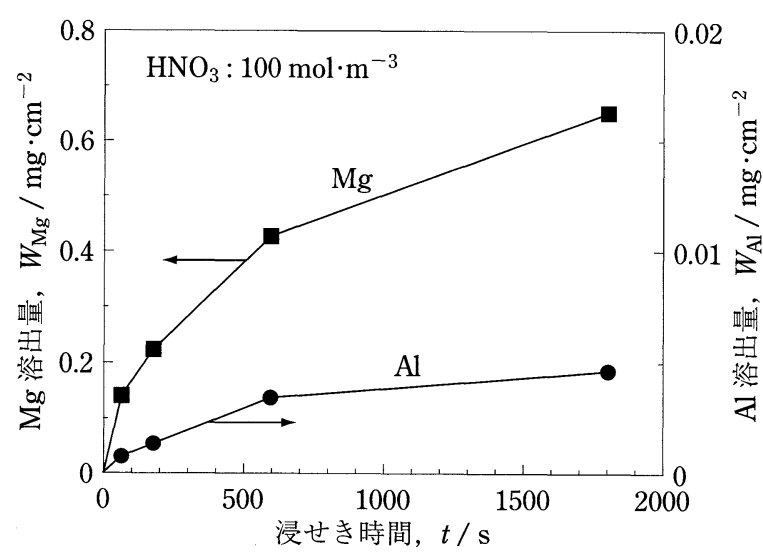

図 3 化成処理浴に溶出する $\mathrm{Mg}$ と $\mathrm{Al}$ 量.
ガン酸カリウム浴を選定した.

図 2 に酸性浴中に抢ける浸せき時間と質量増加の関係を, 図 3 に質量増加の大きい $\mathrm{HNO}_{3}$ 添加浴中に溶出するマグネ シウムとアルミニウムの量におよぼす浸せき時間の影響を示 す。これを見ると皮膜の析出量の増加と溶出量が似たような 傾向を示し，素地の溶出と皮膜の析出が同時に起こっている ことがわかる. 素地の溶解と皮膜の析出機構については, 後 述の皮膜形成プロセスで詳しく述べることにする．また，マ グネシウムとアルミニウムの溶出量の比は, $\mathrm{Mg} / \mathrm{Al} \fallingdotseq 130$ と なっており，合金中のマグネシウムとアルミニウムの平均組 成比が約 10 であることを考えるとマグネシウムの溶出が非 常に大きい。 $\mathrm{Mg}-\mathrm{Al}$ 系合金の AZ91Dの組織は， Mgに A1 が固溶したマトリックスを $\mathrm{Mg}_{17} \mathrm{Al}_{12}$ (金属間化合物析出相) が取り囲むような組織からなっている(10)ことが知られてい るが，溶出量の割合から考えると素材はマグネシウムマトリ ックスが優先的に溶解していると考えられる. すなわち析出 した $\mathrm{Mg}_{17} \mathrm{Al}_{12}$ は腐食電位が貴であり，マトリックスとの間 に局部電池を構成し, マトリックスが溶解するものと考えら れる。一方, HF を添加した浴は, 質量増加も非常に少な く，生成する皮膜も $\mathrm{HNO}_{3}$ 添加に比べ非常に薄い。子っ素 イオンが存在する溶液中ではマグネシウムはふっ素イオンと 反応して不溶性のふっ化マグネシウム $\left(\mathrm{MgF}_{2}\right)$ を生成する ${ }^{(11)}$ ため，これが不働態皮膜として作用し，マグネシウムの溶出 はほとんど起こらないのであろう。このようにマトリックス と存在する化合物, 浴環境下でのそれらの電位差等により, 化成皮膜の形成量が異なることがわかる.

\section{3. 化成処理皮膜の表面状態}

皮膜表面の観察では, $\mathrm{HNO}_{3}$ 添加浴からの皮膜は図 4 から

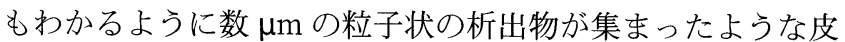
膜であり，浸せき時間の増加に伴う皮膜の成長とともに，化 成処理皮膜によく見られるようなクラックが顕著になる。こ のことは皮膜が水分などを多く含んだ析出物からなっている と考えられる．また時間とともに粒子サイズも少し大きくな るようである。一方, $\mathrm{HF}$ 添加浴加らの皮膜成長は遅く, 非 常に微細な析出物が観察される。

一方, 中性付近から弱アルカリ性浴を用いた場合の析出皮 膜の表面状態は，図 5 に示すように $\mathrm{HCl}$ 濃度により多少異 なっているが，通常のクロメート皮膜のようなクラックの入 った皮膜である。

\section{4. 化成処理皮膜の構造}

\section{(1) $\mathrm{X}$ 線回折による処理皮膜の構造解析}

図 6 は， $\mathrm{KMnO}_{4}$ に $\mathrm{HNO}_{3}$ および $\mathrm{HF}$ を添加した浴からの 化成膜の X 線回折結果である. 特に HF 添加浴からの皮膜 は非常に薄いため入射角を 0.5 度とし, 皮膜からのX 線回折 強度を強くしたが，図からわかるように HF 添加浴からは素 地の $\mathrm{Mg}$ と $\mathrm{Mg}_{17} \mathrm{Al}_{12}$ のピークしか認められない。もし皮膜 

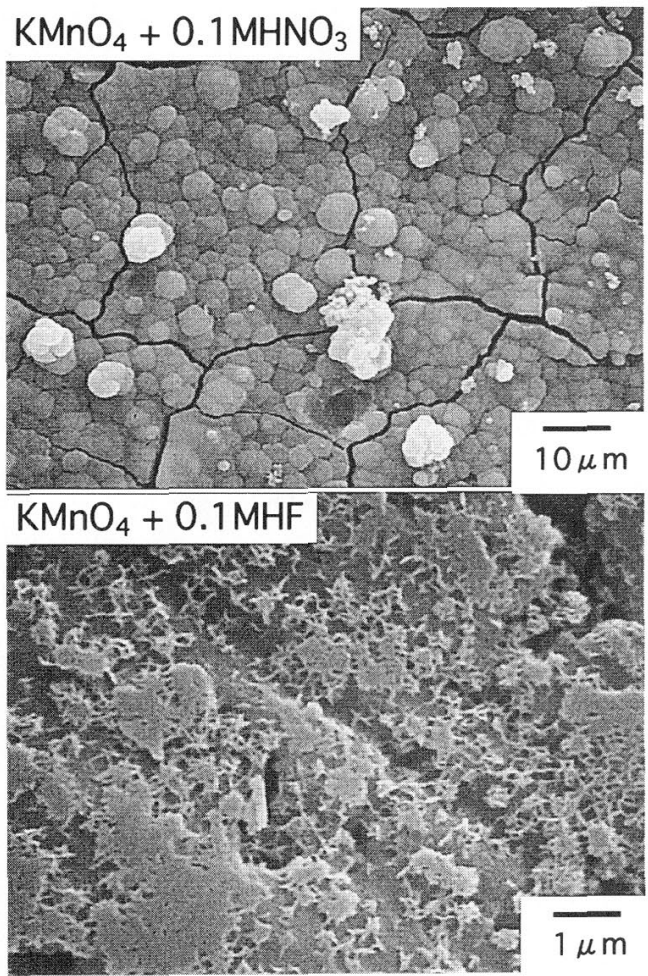

図 4 過マンガン酸浴による化成処理膜の表面状態.

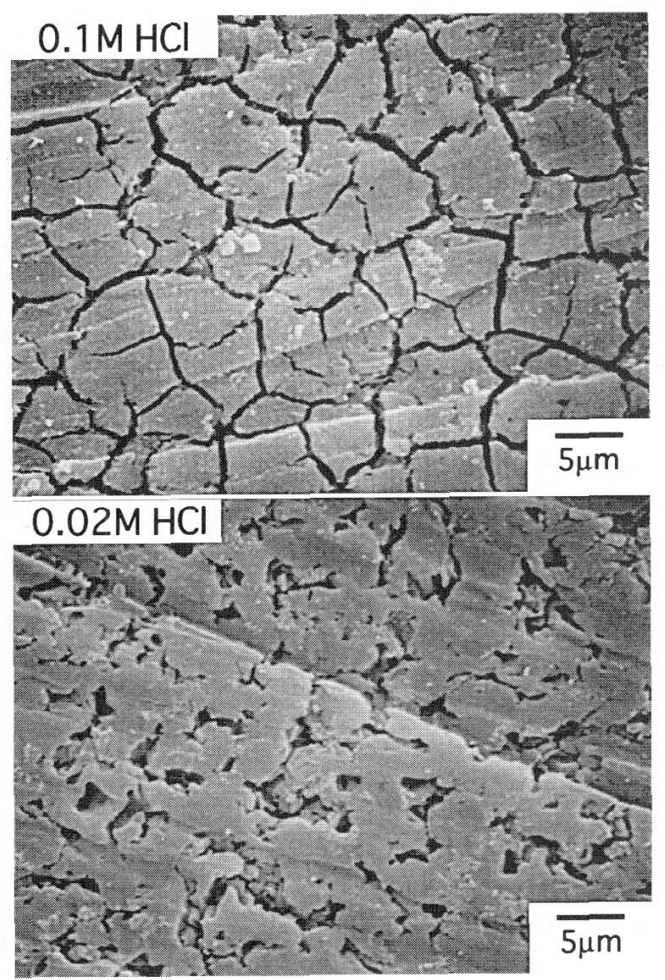

図 5 過マンガン酸浴による化成処理膜の表面状態.

が結晶化していれば，この測定条件では $100 \mathrm{~nm}$ 程度の皮膜 からのピークは十分に観測されることから考えると, HF 添 加浴加らの皮膜は薄くその結晶構造は非晶質であると考光ら れる。一方, $\mathrm{HNO}_{3}$ 添加浴の析出皮膜からは，かなりブロー

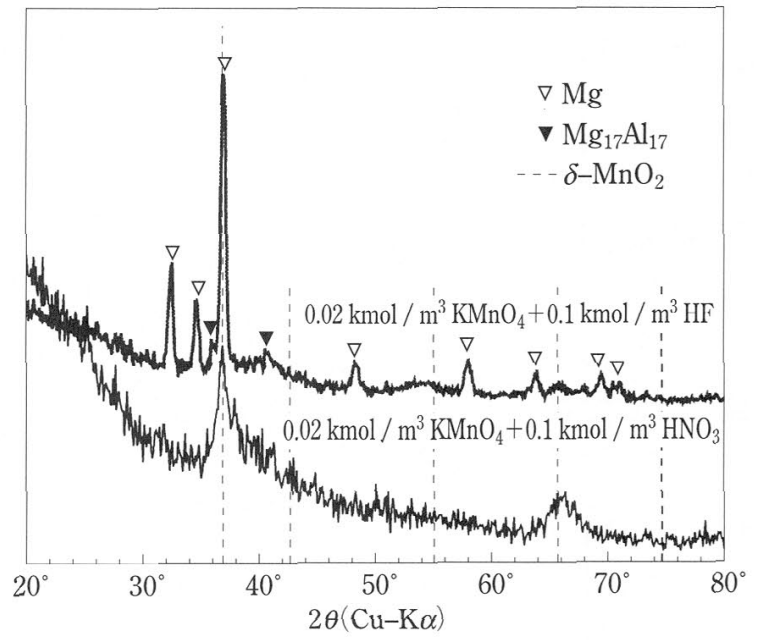

図 6 マンガン系化成処理材の X 線回折結果.

ドでは山るが $\delta-\mathrm{MnO}_{2}$ と思わ机るピークが観察された。こ の回折図加ら素地からのピークが見られないことから, 皮 膜もかなり厚いと考えられる。

$\mathrm{KMnO}_{4}$ と $\mathrm{Na}_{2} \mathrm{~B}_{4} \mathrm{O}_{7}$ を一定としたときの $\mathrm{HCl}$ 濃度を変化 させたときに得られる皮膜の構造は, $\mathrm{HCl}$ 濃度の高い $\mathrm{pH}$ の 低い浴加らの皮膜の析出量は比較的多く, 皮膜の構造も先に 述べた $\mathrm{HNO}_{3}$ 添加浴の析出皮膜上似た構造である. 中性か ら弱アルカリの領域に拈汸る皮膜は $\mathrm{pH}$ が高くなる任ど皮膜 の析出量が減少し, 皮膜の構造は非晶質になる。

\section{(2) $\mathrm{X}$ 線光電子分光分析による処理皮膜の解析}

$\mathrm{X}$ 線光電子分光 $(\mathrm{XPS})$ による分析の結果, $\mathrm{HF}$ 源加浴から 生成した皮膜の組成は $\mathrm{Mn}, \mathrm{Mg}, \mathrm{F}, \mathrm{O}$ からなり, $\mathrm{HNO}_{3}$ 添加 浴加らのものは $\mathrm{Mn}, \mathrm{Mg}, \mathrm{O}$ であり, 他の不純物を含んでい ない。さらに皮膜構成元素の化学状態(結合状態)を見るため, $\mathrm{Mn} 2 \mathrm{p}, \mathrm{Mg}$ 1s, F 1s, O 1s スペクトルを測定した. 図 7 に HF 抢よび $\mathrm{HNO}_{3}$ 添加浴から析出した皮膜のスペクトルを示 す.チャージアップによるエネルギシフトは HF 添加浴から の皮膜はほとんぞなく, 皮膜が非常に薄いことと皮膜に電導 性があることが認められた。各スペクトルデータには, これ まで知られている化合物からのピーク位置のデータ(12)-(19) も併記した。これるで知られているデータと今回得られたデ 一タを比較することで以下のことがわかる，HF 添加浴から の皮膜中のマンガンは酸化物 $\left(\mathrm{MnO}_{2}, \mathrm{Mn}_{2} \mathrm{O}_{3}, \mathrm{Mn}_{3} \mathrm{O}_{4}\right.$ 等 $)$ あ るいは水酸化物の形態をとって抢り(マンガンのピークがブ ロードであるためマンガンにいくつかの化学状態があると考 えられる)，マグネシウムはふっ化物と水酸化物(あるいは酸 化物)の両方の形態をとっていると考光られる．また 0 1s ス ペクトルの高結合エネルギ側にあるピークが水酸基および結 晶水加らのものと考元られ，結晶水を持った酸化物皮膜の存 在も推測される. また $\mathrm{HNO}_{3}$ 添加浴からの皮膜中のマンガ ンもピークの形状から判断して HF 添加浴からのものと同 様, 酸化物あるいは水酸化物の形態をとっていると考えら れ，マグネシウムは水酸化物の形態をとっていると考えられ 

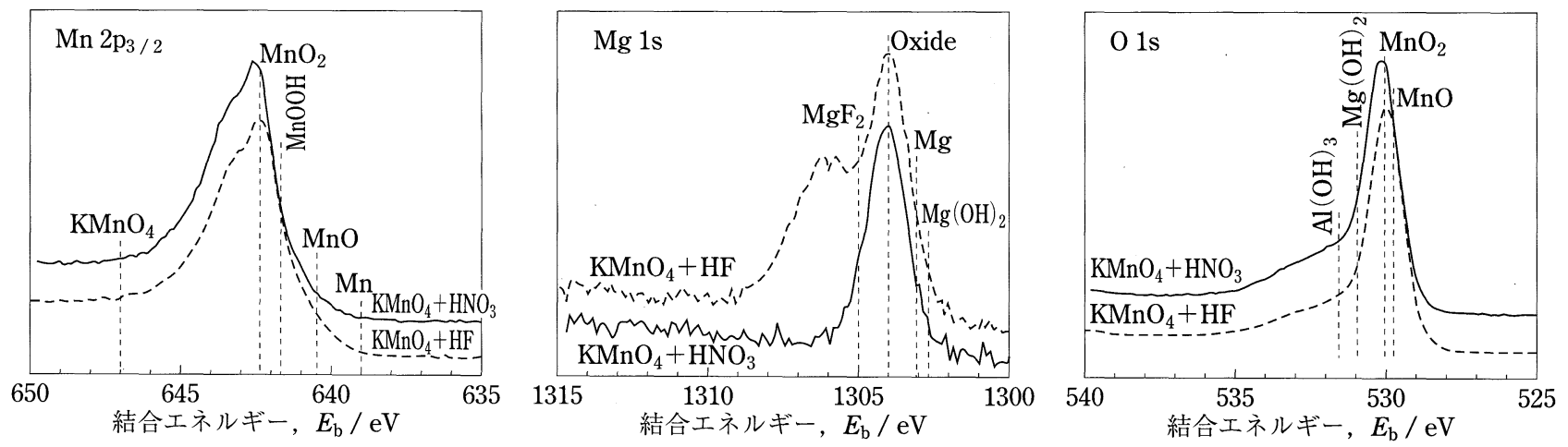

図 7 マンガン系化成処理皮膜のXPS スペクトル.

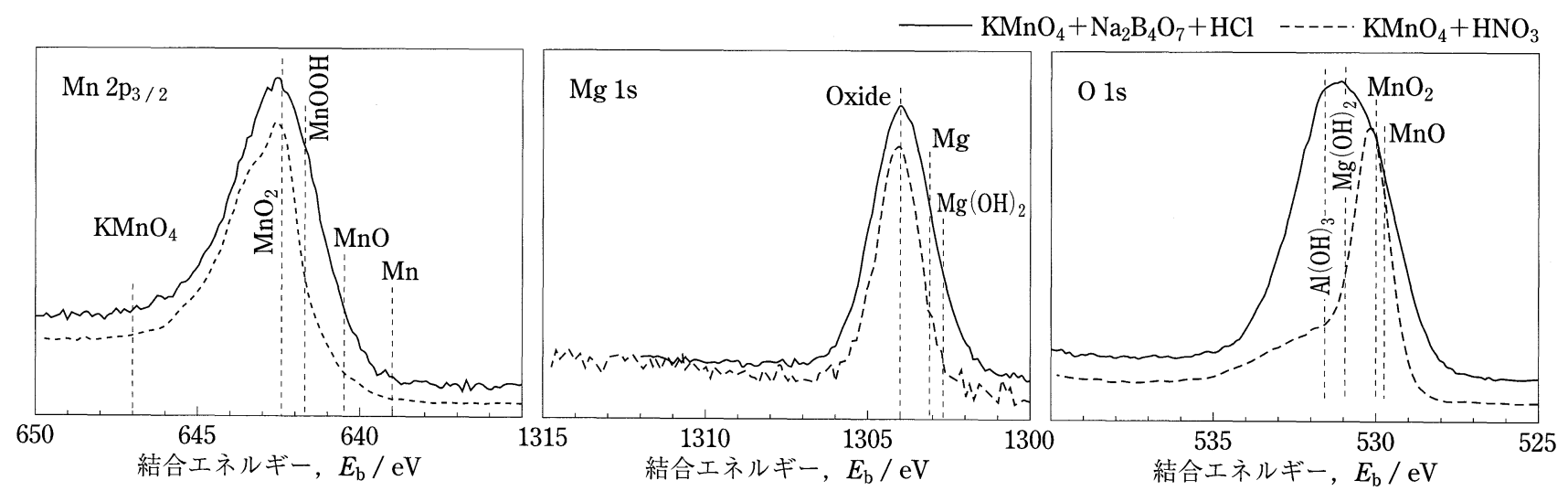

図 8 マンガン系化成処理皮膜の XPS スペクトル.

る.

図 8 に HCl 濃度が $0.1 \mathrm{~mol} / \mathrm{m}^{3}$ の浴から析出する皮膜の XPSによる分析の結果を示す，マンガンとマグネシウムは スペクトルの形状から判断して $\mathrm{HNO}_{3}$ 添加浴からのものと 同様，酸化物あるいは水酸化物の形態をとっていると考えら れる．またホウ素は金属状態ではなく酸化物の状態で存在し ている. 酸素のスペクトルが $\mathrm{HNO}_{3}$ 添加浴 $(\mathrm{HF}$ 添加浴も同 様)に比べて高エネルギ側に広がっているが，これはマグネ シウムとアルミニウムの酸化物(あるいは水酸化物)が他の皮 膜より多いためであると考えられる.

\section{5. 化成処理皮膜の形成プロセス}

これまでの皮膜の分析結果を基に $\mathrm{KMnO}_{4}$ を主成分とした 化成処理浴中における皮膜の形成プロセスについて考えてみ よう. 化成処理浴に浸せきしたときにマグネシウム表面およ び溶液中で起こりうる主な反応を表 1 に示した。これらア） 一ド反応とカソード反応のそれぞれいずれか二つの反応によ って局部電池が構成され，反応が続くと考えられるが，実際 は過電圧や反応速度なども考慮する必要があるため他の組み 合わせになることもある。

中性および酸性領域におけるマグネシウム表面でのアノー ド反応は式 ( 1 )のマグネシウムの酸化反応である。一方,
表 1 マンガン系化成処理浴中における反応.

\begin{tabular}{|c|c|c|}
\hline Mg の酸化 (溶解) & $\mathrm{Mg} \rightarrow \mathrm{Mg}^{2+}+2 \mathrm{e}^{-} \quad\left(E^{0}=-2.363 \mathrm{~V}\right)$ & (1) \\
\hline 水素イオンの還元 & $2 \mathrm{SH}^{+}+2 \mathrm{e}^{-} \rightarrow \mathrm{H}_{2} \quad\left(E^{0}=0 \mathrm{~V}\right)$ & (2) \\
\hline $\begin{array}{l}\mathrm{Mn}^{7+} \text { から } \mathrm{Mn}^{2+} \\
\text { への還元 }\end{array}$ & $\begin{array}{r}\mathrm{MnO}_{4}^{-}+8 \mathrm{H}^{+}+5 \mathrm{e}^{-} \rightarrow \mathrm{M}^{2+}+4 \mathrm{H}_{2} \mathrm{O} \\
\left(E^{0}=1.507 \mathrm{~V}\right)\end{array}$ & (3) \\
\hline $\begin{array}{l}\mathrm{Mn}^{7+} \text { から } \mathrm{Mn}^{3+} \\
\text { への還元 }\end{array}$ & $\begin{aligned} & \mathrm{MnO}_{4}^{-}+8 \mathrm{H}^{+}+4 \mathrm{e}^{-} \rightarrow \mathrm{Mn}^{3+}+4 \mathrm{H}_{2} \mathrm{O} \\
&\left(E^{0}=1.506 \mathrm{~V}\right)\end{aligned}$ & $(4)$ \\
\hline $\begin{array}{l}\mathrm{Mn}^{7+} \text { から } \mathrm{Mn}^{6+} \\
\text { の還元 }\end{array}$ & $\mathrm{MnO}_{4}^{-}+\mathrm{e}^{-} \rightarrow \mathrm{MnO}_{4}^{2-} \quad\left(E^{0}=0.564 \mathrm{~V}\right)$ & ( 5$)$ \\
\hline 溶存酸素の還元 & $\mathrm{O}_{2}+4 \mathrm{H}^{+}+4 \mathrm{e}^{-} \rightarrow 2 \mathrm{H}_{2} \mathrm{O}$ & (6) \\
\hline $\mathrm{Mn}^{7+}$ の還元 & $\begin{array}{r}\mathrm{MnO}_{4}^{-}+4 \mathrm{H}^{+}+3 \mathrm{e}^{-} \rightarrow \underset{\left(E^{0}=1.692 \mathrm{~V}\right)}{\mathrm{MnO}_{2}+2 \mathrm{H}_{2} \mathrm{O}}\end{array}$ & ( 7 ) \\
\hline & $\begin{array}{r}\mathrm{MnO}_{4}^{-}+2 \mathrm{H}_{2} \mathrm{O}+3 \mathrm{e}^{-} \rightarrow \underset{\left(E^{0}=0.588 \mathrm{~V}\right)}{\mathrm{MnO}_{2}+4 \mathrm{OH}^{-}}\end{array}$ & $(8)$ \\
\hline
\end{tabular}

カソード反応は $(2) \sim(8)$ のようなものが考えられるが， 比較的電位の高い反応は, 式 (3), (4), ( 7 )である. 式 ( 3 ) 抢よび (4) は電位-pH図 ${ }^{(20)}$ からわかるように $\mathrm{pH}$ の非 常に低い領域での反応であるため, 式 $(7)$ の反応が起こり そうである．そこで皮膜形成の反応は，以下のように考えら れる(皮膜形成概念図を図 9 に示す). マグネシウムを過マン ガン酸塩を含んだ化成処理浴に浸せきすると，アノード反応 としてマグネシウムが溶出する反応が起こる.これに対応す るカソード反応として過マンガン酸イオン $\left(\mathrm{MnO}_{4}^{-}\right)$の還元反 応により, $\mathrm{MnO}_{2}$ が生成する. カソード領域では局部的に 


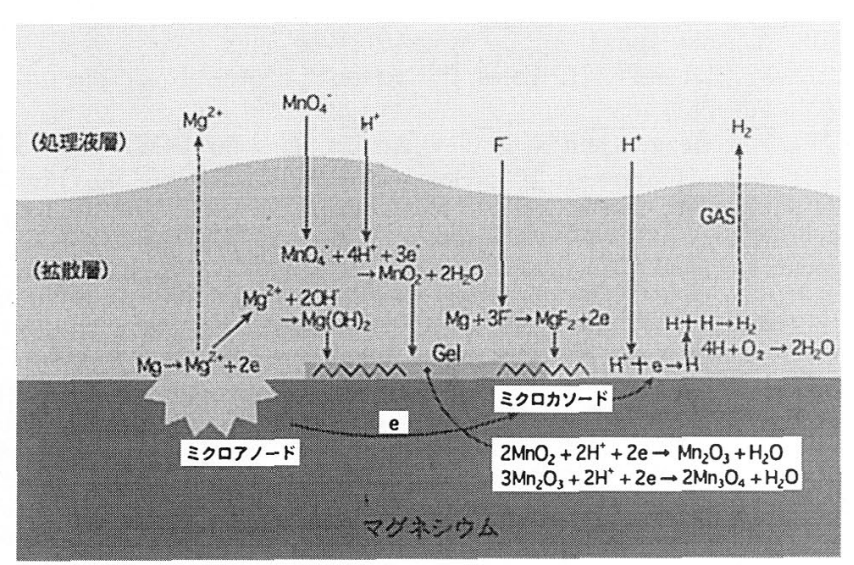

図 9 マンガン系化成処理反応の模式図.

$\mathrm{pH}$ が上昇し, $\mathrm{MnO}_{2}$ から低次の酸化物への還元反応 (中性か らアルカリ溶液中で生じる) も起こり, 種々の酸化物の共存 した皮膜が生成すると考えられる。

また, HF 添加浴では上記の反応に加え, マグネシウムと 溶液中のふっ素イオンが反応して不溶性のマグネシウムのふ っ化物を生成するため，マグネシウムのふっ化物と種々のマ ンガンの酸化物の共存した皮膜が生成すると考えられる.

\section{6. 化成処理材の電気化学的挙動と耐食性}

過マンガン酸塩浴からの化成皮膜の耐食性を評価するため に塩素イオンを $50 \mathrm{~mol} / \mathrm{m}^{3}$ 含む溶液中化成処理材の耐食性 を評価するため，クロメート系およびマンガン系化成処理を 施したマグネシウム合金の塩素イオンを含む溶液 (50 mol/ $\mathrm{m}^{3} \mathrm{NaCl}+500 \mathrm{~mol} / \mathrm{m}^{3} \mathrm{Na}_{2} \mathrm{SO}_{4}$ ) 中に抢ける分極曲線の測定 も行った。自然電位は AZ91D が約-1.6 V (vs Ag/ AgCl)で $\mathrm{HF}$ 添加浴のものがそれよりやや低く, $\mathrm{HNO}_{3}$ 添加浴のもの がやや高い值を示した．特に HF 添加浴からの試料はアノー ド曲線に少しではあるが不働態を示し，AZ91Dに比較して アノード分極が大きくなっており，耐食性に優机ているもの と思われる. また $\mathrm{HNO}_{3}$ 添加浴加らの試料も AZ91D に比べ アノード分極が大きくなっている. $\mathrm{Na}_{2} \mathrm{~B}_{4} \mathrm{O}_{7}$ と $\mathrm{HCl}$ 添加浴 からのマンガン系化成処理皮膜の分極曲線を図10に示す。こ の結果を見ると $\mathrm{HCl}$ 濃度が $100 \mathrm{~mol} / \mathrm{m}^{3}$ (浴の $\mathrm{pH}$ が約7.8)の 処理浴から得られる皮膜は腐食電位が AZ91Dより高く, し かもアノード分極曲線に不働態を示すとともに AZ91Dに比 べ分極が大きくなって扔り，耐食性が期待できる.

一部の化成処理を施したマグネシウム合金の耐食性評価に は， $5 \% \mathrm{NaCl}$ 水溶液を用いた連続塩水噴霧試験を行った。 塩水噴霧試験 $2.6 \times 10^{2} \mathrm{ks}$ 後の見掛けの腐食面積率およびレ イティングナンバによる評価の結果, 酸性の過マンガン酸浴 $\left(\mathrm{KMnO}_{4}+\mathrm{HNO}_{3}\right)$ では浴温の高い浴からの皮膜が, $\mathrm{MX} 3$ 種 浴 $\left(\mathrm{Ma}_{2} \mathrm{Cr}_{2} \mathrm{O}_{7}+\mathrm{CaF}_{2}\right)$ からの皮膜とほぼ同一の耐食性を示し ていた。 また中性付近から弱アルカリ性浴から得られる皮膜 の塩水噴霧試験後の腐食面積率(レイティングナンバ)による 耐食性評価の結果を図11に示す。これを見ると処理温度より

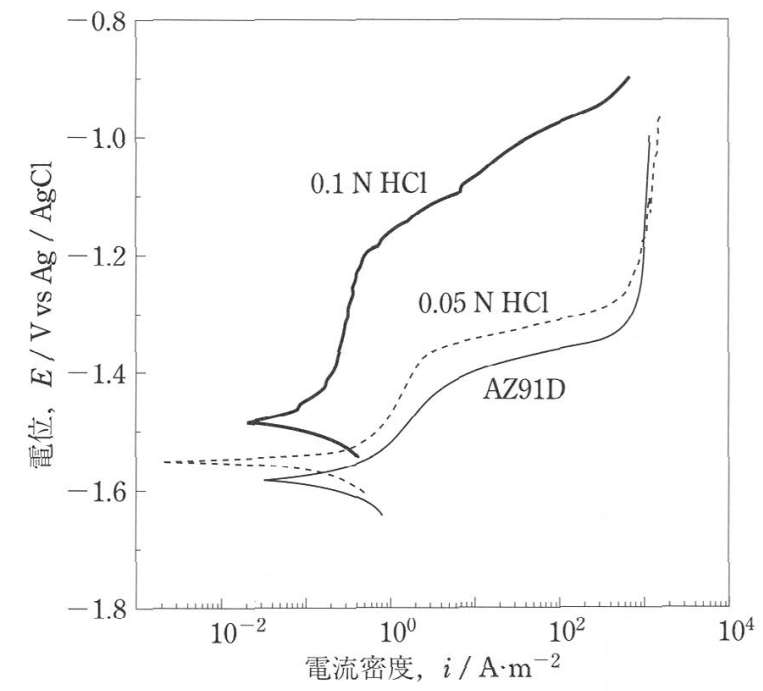

図10 マンガン系化成処理皮膜の分極曲線.

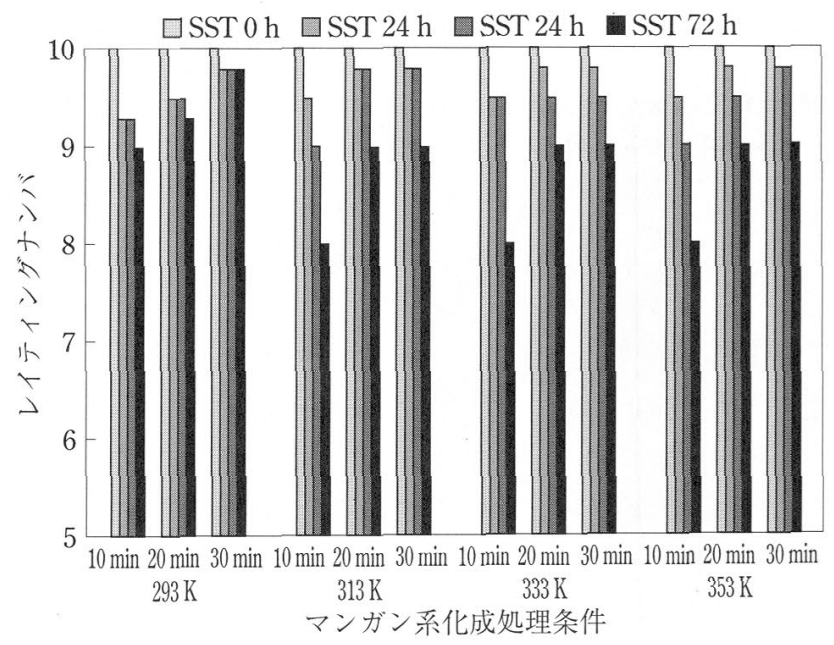

図11 マンガン系化成処理材の塩水噴霧試験結果.

処理時間が長いものが比較的耐食性に優れていることが分か る.

\section{7.おおりに}

本報告では，マグネシウムおよびその合金に対する表面処 理技術, 表面処理を取り巻く環境問題の動向, 環境調和の観 点からの過マンガン酸塩を主体としたマンガン系化成処理法 の概要, 得られたマンガン系化成皮膜の形状や皮膜構造に関 する解析結果，また，マンガン系化成処理材の電気化学特性 や耐食性について紹介した。最初にも述べたように，マグネ シウム合金に対するクロムフリー化成处理技術の開発は，近 年盛んに行われているが, またクロメート処理と同様の廉価 で耐食性に優れた処理技術は開発されていない。今後, コス トと品質性能を有する環境に優しい表面処理技術が開発され るものと期待される。 


\section{文献}

（1）例えば，J1S によるマグネシウム合金阴食処理力法（H86511994).

（2）熊谷正夫，池田 哲：金属表面技術，38(1987), 564.

(3) J. W. Bibber: Metal Finishing, 91 (6) (1993), 46.

（4）佐藤敏彦，神長京子：塗装技術， 7(1994)，46.

（5）高谷松文: 軽金属，45(1995), 713

(6) D. Hawke and D. L. Albright: Metal Finishing, 93(10) (1995), 34.

( 7 ) M. A. Gonzalez-Nunez, C. A. Nunez-Lopez, P. Skeldon, G. E. Thompson, H. Karimzadeh, P. Lyon and T. E. Wilks: Corros. Sci., 37 (1995), 1763.

（8）松村健樹：塗装技術, 38(2)(1999), 62.

（9）遠藤千代子：塗装技術，38(2) (1999)，67.

(10) O. Lender, J. E. Lein, S. M. Hesjevik, T. Kr. Aune and K. Nisancioglu: Werkstoffe und Korrosion, 45 (1994), 331.

(11) S. Yamaguchi: J. Appl. Phys., 25 (1954), 1437-1438.

(12) J. Chastain: Handbook of X-ray Photoelectron Spectroscopy, Perkin-Elmer Co.

(13) C. D. Wagner: J. Electron Spectrosc. Relat. Pheom., 18 (1980), 345.

(14) Y. Inoue and I. Yasumori: Bull. Chem. Soc. Jpn., 54(1981), 1505.

(15) D. E. Haycock, M. Kasoud, C. J. Nicholls and D. S. Urch: Chem. Soc. Dalton Trans., (1978), 1791.
(16) A. Aoki: Jpn. J. Appl. Phys., 15 (1976), 305.

(17) M. Oku and K. Hirikawa: J. Electron Spectrosc. Relat. Pheom., 7 (1975), 465

(18) Y. Umezawa and N. Reilley: Anal. Chem., 50 (1978), 1294.

(19) A. E. Hughes, R. J. Taylor and B. R. W. Hinton: Surf. Int. Anal., 25(1997), 223

(20) M. Pourbaix: Atlas of Electrochemical Equilibria in Aqueous Solulions, Chap. 11, Sec. 11.1, Pargamon Press, Oxford, (1966).

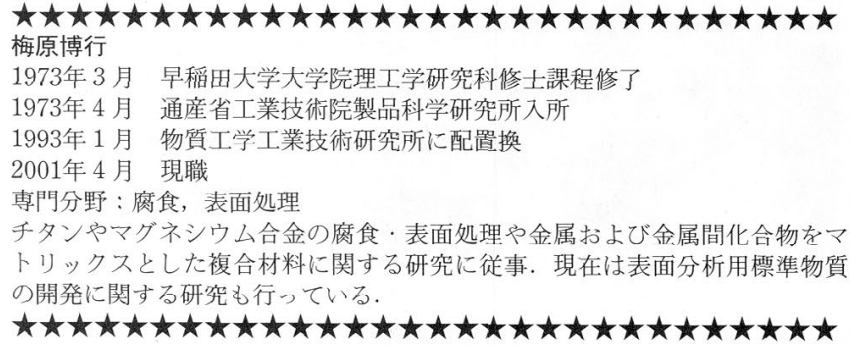

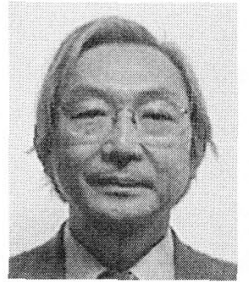

梅原博行

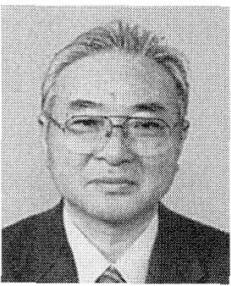

高谷松文 